Sakarya Üniversitesi İlahiyat Fakültesi Dergisi

Journal of Sakarya University Faculty of Theology

ISSN: 2146-9806 | e-ISSN: 1304-6535

Cilt/Volume: 22, Sayı/Issue: 41, Yı1/Year: 2020 (Haziran/June)

\title{
Bir Katl Davası Işığında Cebel-i Lübnan'da Tanzimat Hukukunun Dürzî Kimliğine Yansıması
}

The Reflection of the Tanzimat Law on Druze Identity in Mount Lebanon in the Light of a Murder Case

\section{Tuba Yıldiz}

Arş. Gör. Dr., Trakya Üniversitesi, İlahiyat Fakültesi, İslam Tarihi Ana Bilim Dalı Res. Asst., Ph.D., Trakya University, Faculty of Theology, Department of Islamic History.

\author{
tubayildiz@trakya.edu.tr \\ https://orcid.org/0000-0002-7152-4421
}

\section{Makale Bilgisi - Article Information}

Makale Türü/Article Type: Araştırma Makalesi/ Research Article

Geliş Tarihi/Date Received: 25/03/2020

Kabul Tarihi/Date Accepted: 08/05/2020

Yayın Tarihi/Date Published: 15/06/2020

Atıf/Citation: Yıldız, Tuba. “Bir Katl Davası Işı̆̆ında Cebel-i Lübnan'da Tanzimat Hukukunun Dürzî Kimliğine Yansıması". Sakarya Üniversitesi İlahiyat Fakültesi Dergisi 22/41 (2020): 227-245. https://doi.org/10.17335/sakaifd.709368

İntihal: Bu makale, iThenticate yazılımı ile taranmış ve intihal tespit edilmemiştir. Plagiarism: This article has been scanned by iThenticate and no plagiarism detected.

Copyright (C Published by Sakarya Üniversitesi İlahiyat Fakültesi - Sakarya University Faculty of Theology, Sakarya/Turkey. 


\title{
Bir Katl Davası Işığında Cebel-i Lübnan'da Tanzimat Hukukunun Dürzî Kimliğine Yansıması*
}

\section{öz}

Osmanlı yönetiminin Tanzimat’ı ilanı, temelde merkezileşmeyi öngörmekle birlikte modern bir Devlet kurma çabasını da temsil ediyordu. Bu nedenle Kasım 1839'da ilan edilen ferman, bir anlamda Devletin iç ve dış kontrolünün zayıflığının 18. yüzyılda belirginleşmeye başlamasından sonra yeni yasalar ile güvenliği sağlamak, yolsuzluğa son vermek, vergilendirmeyi ve askerliği düzene sokma çağrısıydı. İmparatorluğun siyasi, askeri ve idari alanda yaptığı bu devrimin en büyük payını da hukuki sistem oluşturmuştu.

Tanzimat'ın yarattığı yeni hukuki çehreyi taşraya özellikle de Cebel-i Lübnan gibi mezhep hukukunun etkili olduğu bir bölgeye oturtturmak ise kolay olmadı. Bu noktada bölgenin en önemli mezhep gruplarından biri olan Şiî Dürzîlerin kendilerini yeniden tanımlama çabaları bölgenin diğer önemli mezhep grubu olan Katolik Mârûnilerle çatışmaların yanı sıra Devletle olan ilişkileri bağlamında hukuk-kimlik çerçevesinde de kendisini gösterdi. Cebel-i Lübnan'daki güç mücadelesinin önemli aktörlerinden olan Dürzîlerin dönüşen hukuki statüleri bir yandan Devlet- toplum ilişkilerinin boyutunu ortaya çıkarırken, diğer yandan Tanzimat reformlarının üzerinde durduğu "Osmanlılık" kimliğinin Cebel-i Lübnan'daki karşılığının ne olduğu sorusunun sorulmasına neden oldu.

Anahtar Kelimeler: Tanzimat Dönemi, Hukuk, Cebel-i Lübnan, Dürzîler.

\section{The Reflection of the Tanzimat Law on Druze Identity in Mount Lebanon in the Light of a Murder Case}

\begin{abstract}
The proclamation of the Tanzimat by the Ottoman administration represented not only a fundamental centralization but also an attempt to transform into a modern state. Therefore, the edict issued in November 1839, was a call to put taxation and military into order, ensure security, put an end to corruption with new regulations after the weakness of the internal and external control of the state has become prominent in 18th century. In this sense, the most important part of the revolution of the Empire in the political, military and administrative area was the legal system. It was not easy to settle the new legal framework created by the Tanzimat regime in a region such as Mount Lebanon where sectarian law was influential. At this point, the efforts of the Shite Druzes, one of the most important sect groups of the region, to redefine themselves in the context of the relationship with the state between law and identity as well as the conflicts with Maronites, the other important sectarian group in the region, have emerged. The transforming of the legal status of the Druze, which is one of the important actors of the power struggle in Mount Lebanon, reveals the dimension of the state-society relations, and leads us to the question that what is the meaning of "Ottoman identity" the Tanzimat reforms emphasized in Mount Lebanon.

[You may find an extended abstract of this article after the bibliography.]
\end{abstract}

Keywords: Tanzimat Era, Law, Mount Lebanon, Druzes.

\section{Giriş}

Fâtımîlerin 6. Halifesi olan Hâkim Bi Emrillah tarafından ilan edilen Dürzîlik, İsmâililik'ten neşet etmekle birlikte inanç esaslarını Hâkimin uluhiyetine dayandıran bir mezhepti. 909'da Mısır'da Fâtımî devletinin Ebû Abdullah elMehdî liderliğinde İsmâili esaslar üzerine kurulması, mezhebin ilk defa bir

* Bu çalışma 2018 yılında İstanbul Üniversitesi S.B.E. İslam Tarihi ve Sanatları Bölümünde hazırlanan "Cebel-i Lübnan'da Osmanlı Devleti'nin Mezhep Politikası ve Hukuki Uygulamalar (1839-1914)" isimli doktora tezinden üretilmiştir. 
devletin resmî ideolojisi olmasına ve kurumsallaşmasına zemin hazırlamış, İsmâili propaganda, devlet tarafından mezhebin propagandistleri olan dâiler eliyle yayılarak, Fâtımî halifelerinin imamlar olarak meşruiyetlerinin sağlanmasına çalışılmıştı. ${ }^{1}$ Teolojik meselelerin siyaset zeminine taşınmasıyla da İsmâili akide yeniden şekillenmiş ve dini anlayışın yeniden yorumlanması meselesi ortaya çıkmıştı. ${ }^{2}$ Özellikle mehdîlik anlayışı çerçevesinde açılan yeni başlıklar mezhebin bir anlamda politize edilerek farklı mecralara kaymasına, doğal olarak da içerde bir takım kırılmaların meydana gelmesine yol açmaktaydı. Fâtımî Devleti'nin mezhep eksenli yürüttüğü bu tarz siyasi anlayışının bir neticesi olarak ise yeni fikri akımları meydana gelmeye başlamış, Hâkim bi Emrillah döneminde mehdîlik tartışmaları son bulmuş olsa da İsmâili akîdenin daha ileri boyuta taşınması söz konusu olmuştu. Dürzîlik de İsmâili öğretileri inanç esaslarının şekillenmesinde temel alan ancak ideolojik farkl1lık nedeniyle kopan bu hareketlerden biri olarak doğmuş, 1017 yılında da imam Hamza b. Ali'nin önderliğinde Hâkim bi Emrillah'ın uluhiyetine inanan Dürzîler, yeni bir mezhebin takipçileri olarak Mısır'da yayılmaya başlamişlardi ${ }^{3}$

Dürzîlerin Cebel-i Lübnan topraklarında isimlerinin duyulması ise -tartışmalı olsa da- Hâkim bi Emrillah'ın 11. yüzyıl başında Dürzî dâilerden Anuştekin Derezî’yi mezhebi anlatması için görevlendirmesi neticesinde gerçekleşti. Buna göre Dürzîlik, Anuştekin vasıtasıyla önce Teym vadisi taraflarında taraftar buldu, sonrasında burada bulunan toplulukların Şuf, Metn ve Havran dolaylarına göç etmeleriyle Lübnan'da Hâkim'e inanan bir Dürzî topluluğu ortaya çıkmasıyla yayılmaya başladı. ${ }^{4}$ Mezhebin Hâkim'den sonraki stratejik lideri Hamza b. Ali de cemaati muntazam bir şekilde sistemleştirerek Ürdün ve Filistin'de de yayılmasını sağladı, bu sayede koyduğu yeni din anlayışıyla da mezhebin günümüze kadar gelmesinde öncülük etti. Hamza b. Ali'den sonra gelen Muktenâ Bahaeddin'in 1042'deki gaybetiyle ise cemaat herhangi bir liderin prensibini benimsemeyen, ayrıca dışardan üye kabul etmeyen ve mensuplarının cemaatten ayrılmasına müsaade etmeyen radikal bir mezhep haline geldi. ${ }^{5}$

1 Kais Firro, A History of The Druzes, (Leiden: E.J. Brill, 1992), 7.

2 Ahmet Bağlığlu, İnanç Esasları Açısından Dürzîlik (Ankara: Ankara Okulu Yayınları, 2004), 45 .

3 Silvestre De Saci, Medhal ilâ Diyâneti Düruz, çev. İsa Tannus (Şam: Dârü'l Vataniyyetü'1 Cedîde, 2011), 376.

4 Charles Henry Churchill, The Druzes And The Maronites: Under The Turkish Rule From 18401860, (Reading: Garnet Publishing, 1994), 11; Nejla M. Abu-Izzeddin, The Druzes: A New Study of Their History and Faith (Leiden: E.J. Brill, 1984), 127.

5 Ahmet Bağlıŏglu - Sıddık Ünalan, Ortadoğu'da Marjinal Bir Topluluk Dürzîler: Son Rapor (Elazığ: Fırat Üniversitesi İlahiyat Fakültesi, 2005), 21. 
1516 yılında Suriye ve Lübnan'ın Osmanlı hâkimiyetine girmesiyle birlikte bölgede yaşayan Dürzîlerin Osmanlı tebaasına dahil olmaları, cemaatin Millet Sistemi içindeki statülerinin belirlenmesi gerekliliğini ortaya çıkardı. Bu noktada Osmanlı yönetimi Dürzîleri Ehl-i İslam'dan saymadı ancak Râfızî olarak da adlandırmayı tercih etmedi ve inanç sistemlerini sorgulamadı. ${ }^{6} \mathrm{Bu}$ nedenle de kapalı bir toplum olsalar da askeri ve idari yetenekleri olan Dürzîlerin Cebel-i Lübnan'daki Emirlik düzenini yönetmelerine müsaade edildi. Dürzî liderler de 19. yüzyılın ortalarına kadar zaman zaman çıkan huzursuzluklar dışında Osmanlı Devleti'yle uyumlu bir politika sergilediler.

1841 yılında Cebel-i Lübnan'da Dürzîler ile Mârûniler arasında başlayan çatışmalar ise Kavalalı İbrahim Paşa'nın yönetiminden henüz çıkmış olan bölgenin idari ve siyasi yapısının değişmesine yol açan en önemli sebeplerden biri oldu. Çatışmalardan sonra 1845 yılında kurulan “Çift Kaymakamlık Sistemi” ile Cebel-i Lübnan ilk defa iki ayrı kaymakamlığa ayrılmış, otoriteyi ellerinde tutan Dürzîler bölgeyi 1860 yılına kadar Mârûnilerle birlikte paylaşmak durumunda kalmışlardı. ${ }^{7}$ Bu noktada bölgenin en önemli mezhep gruplarından biri olan Şiî Dürzîlerin, bölgenin diğer önemli mezhep grubu olan Katolik Mârûnilerle çatışmaları sonucunda siyaseten güç kaybına uğramaları, devletle olan ilişkilerini hukuk-kimlik çerçevesinde değerlendirmelerinin önünü açtı. Bunun yanı sıra, Cebel-i Lübnan'daki güç mücadelesinin önemli aktörlerinden olan Dürzîlerin dönüşen hukuki statüleri bir yandan devlettoplum ilişkilerinin boyutunu ortaya çıkarırken, diğer yandan Tanzimat reformlarının üzerinde durduğu "Osmanlılık" kimliğinin Dürzî cemaati için ne olduğu sorusunun sorulmasına neden oldu.

$\mathrm{Bu}$ noktadan hareketle bu araştırma 19. yüzyılda Osmanlı Devleti'nin içinde bulunduğu sosyo-politik atmosfer içerisinde Cebel-i Lübnanlı Dürzîlerin kendilerini yeniden tanımlama çabaları karşısında ortaya koyduğu refleksi incelemektedir. Çalışma 1848 yılında bir Mârûni'nin bir Dürzî́yi öldürmesi sonucu Sadâret'e uzanan bir katl davasında verilen hükmü ele alarak hem Dürzî kimliğinin hem de cemaatin hukuki statüsünün nasıl tanımlandığı sorusuna cevap aramış, devlet-toplum ilişkilerinde dini/mezhebi izdüşümün yansımalarını ele almıştır. Bu anlamda çalışmada Osmanlı Devleti'nin mezhep politikaları bağlamında gayri Sünni olan bir gruba yaklaşımı gösterilerek, etnik ve dini çeşitliliğe en fazla sahip olan bölgelerden biri olmasının yanı sıra uluslararası siyasetin de ağırlığının hissedildiği Cebel-i Lübnan'da mezhepsel dengeyi kurma noktasında belirlenen pragmatik siyasetin sonuçlarını ortaya koymak hedeflenmiştir.

6 Osmanlı Arşivi (BOA), Mühimme Defteri, [MD], No. 29, 70, 25.

7 Osmanlı Arşivi, (BOA), Bâbıâli Evrak Odası Gelen Giden Defterleri [BEO, GG], No. 1013, 1. 


\section{Dürzî İnanç Esasları ve Osmanlı Devleti'nde Dürzîler}

\subsection{Dürzî İtikadının Temelleri}

Dürzîliğin doğuşunu hazırlayan temel etmen Hâkim bi Emrillah'tan sonra mezhebi sistematize eden dâî Hamza b. Ali'nin Hâkim'e ulûhiyet atfederek onun yarattığı varlıkların ilâhi bir kategoriye tabi tutulmasıyla oluşan ideolojiydi. Buna göre Hâkim'e özel hizmetlisi Hamza b. Ali bir mezhep va'z etmiş, buna da Dürzîlik adını vermişti. ${ }^{8}$ Hâkimin hiçbir sıfatla tanımlanamayacağı, onun hiçbir şeye benzemediği, eşinin ve benzerinin olmadığ 1 inancı mezhebin ana akidesi olmuş, bu sebeple de Dürzîlik, İsmâililikten koparak kendi inanç, ilke ve şartlarını belirlemişti. ${ }^{9}$ Bu noktada Hâkim bi Emrillah, Tanrı'nın tecelli ettiği 72. insan bedeni olarak kabul edilmiş, Dürzî inanç akidesi bu inanç çerçevesinde şekillenmeye başlamıştır. ${ }^{10}$ Mezhebin kutsal kitabı olarak kabul edilen Resâilü'l Hikme'de bu vurgu, “Tanrı'nın yarattı̆̆g varlıkların suretinde kendi varlığını ortaya koyması "şeklinde ifade edilmiştir. ${ }^{11}$

Dürzîlerin akîdevi bağlamda temellerini oluşturan bir başka husus diğer dinlerin nesh edilmiş olduğu düşüncesiydi. Buna göre Tanrının Hâkim'e tecelli etmesiyle kendisinden önceki tüm dinler ve bu dinlere bağlı olan mezheplerin hepsi geçerliliğini yitirmiştir. Bu noktada ortaya çıkan mesele ise, İslam dininden neşet eden bir mezhebin kolu olan Dürzîliğin İslam dinini de bu akîde çerçevesinde tevil etmiş olduğudur. Akîdeye göre nasıl ki Hristiyanlık İslam dininin doğuşuyla son bulmuş, Dürzîliğin doğuşuyla da İslam dininin ilkeleri ortadan kalkmıştır. ${ }^{12}$

Mezhebin ibadetler konusundaki yöntemi de yine nesh merkezli olmuş, İslamın beş şartı tevil edilerek zâhirî anlamları ortadan kaldırılmış ve bâtınî hükümler konulmuş, konulan hükümlerin hepsi de Hâkim'in birliği ve ulûhiyeti merkezinde toplanmıştır. Bu aşamada Dürzî inancına göre Kelime-i Şehadet, tevhidin her devirde Hâkim bi Emrillah için olduğunu kabul etmenin yanı sıra, akıl ve nefse işaret etmektedir. ${ }^{13}$ Beş vakit kılınması öğretilen namaz ise doğru sözlü olmayı temel alırken kalplerin hiçbir şerîki olmayan Hâkim'in tevhidiyle birleşmesi anlamını taşımaktadır. ${ }^{14}$ Oruç ibadetinin de suskunluk olarak nitelendiği Resâilü'l-Hikme'de, oruç, var olmayan ve yalan şeylere ibadeti terk etmek olup, şeriat-1 zâhire ashabıyla - Ehl-i Sünnet- ile ${ }^{15}$ konuşma-

8 İzmirli İsmail Hakkı, Dürzî Mezhebi (İstanbul: Evkâf-1 İslamiyye Matbaası, 1926), 24.

9 Ahmet Bağlığlu, Inanç Esasları Açısından Dürzîlik, 155.

10 Şenzeybek, Ana Kaynaklarına Göre Dürzîlik, 53.

11 Resâilü'l- Hikme (Beyrut: Dâru Liecli'l-Meârife, 1986), Mi'râcu Necâti'l-Muvahhidîn, 69/588.

12 Şenzeybek, Ana Kaynaklarına Göre Dürzîlik, 295 - 296.

13 Resâilü'l-Hikme, en-Nakzü'l-Hafiyy, 6/50.

14 Resâilü'l-Hikme, en-Nakzz̈̈l-Hafiyy, 6/56.

15 İzmirli İsmail Hakkı, Dürzî Mezhebi, 78. 
mak ve kalbi Hâkim'in birliğiyle korumak, diğer temeller olarak belirlenmiştir. ${ }^{16}$ Zekat ise din kardeşini korumakla birlikte yine Hâkim tarafından zâhir ve bâtını kaldırılan, hakikatte Mevlâ olan Hâkim'in birliğiyle kalpleri tezkiye etmek ve temizlemek şeklinde eda edilecek bir ibadet olarak ifade edilmiştir. Son olarak Hac ibadetini de iblislerden ve azgınlardan uzaklaşmak olarak tevil edip, yanı sıra Haccı Hâkim'in tevhidi üzerinden yorumlayan metinlerde, Kâbe'nin rabbinin Hâkim olduğunu vurgulanmış, Mevlâ'nın birliğiyle huzura kavuşulacağ 1 zikredilmiştir. ${ }^{17}$

Dürziler, iman ve ibadet esaslarının yanı sıra Tanrının birliğinin, sonsuzluğunun, başlangıcının ve sonunun olmamasının, insanı tanımlayan ruh ve beden kavramlarının çok ötesinde olmasının yanı sıra Hâkim, Hududlar ve ra'iyye üzerine inşa edilen inanç sistemi bağlamında kendilerini tanımlamışlardır. Bunun yanı sıra mezhep müntesiplerinin "tevhid ehli- muvahhidun" olduklarına nispet edilmiş, kavramsal çerçevede de ayrı bir doktrin oluşturulduğu gösterilmeye çalışılmıştır.

\subsection{Osmanlı Devleti için Dürzî Kimliği}

Fatih Sultan Mehmed'in yükselen siyasetiyle birlikte resmî ideolojinin Sünnî İslam çerçevesinde belirlenmiş olmasının, îtikâdi olarak Sünnî-Mâturîdi amelî olarak da Hanefiliğin kurumsallaşmasını beraberinde getirdiği açıktır. Klasik Sünni anlayışın teorik ve pratik yansımalarının merkez bürokraside ve medreseler aracılığıyla eğitim kurumlarında siyasi, sosyal ve hukuki teşkilatlanma üzerinde yaygınlaşması zamanla devletin "resmî" bir mezhebinin olmasına yol açmıştır. ${ }^{18}$ İslam'ın Sünnî-Hanefi yorumunun özellikle 16. yüzyılda ortaya çıkan Safevî ideolojiye karşı Osmanlı iktidarıyla bütünleşmiş olması ise, tebaadan Sünnî olmayanların hangi siyasi hüviyete sahip oldukları sorularını gündeme getirmiştir. Bu bağlamda devletin kontrolü dahilinde idealize edilen Sünnîliğin siyasi normlarının büyük ölçüde halka empoze edilmiş olması, buna karşı olan birtakım çıkışların da üstüne gidilmesine sebep olmuştur.

1577'de Bolu Sancağı beyine ve Milas ile Kurşunlu kadılarına gönderilen hüküm bu yönde belirlenen çizginin bir göstergesi gibidir. Hükümde Hanefi, Mustafa ve Abdi'nin Râfızi olduklarının ihbar edildiği yer alıyor, ancak vilayetten kırk kişinin bu adamların Sünnî olduklarına dâir şehadet edip durumun teftiş ve tahkik edilmesi gerekliliği bildirilerek tedbir alınması emrediliyordu. ${ }^{19}$ Şirvan hâkimi Ebûbekir Mirza'ya gönderilen hükümde ise İran'a

16 Resâilü'l-Hikme, en-Nak̨zü'l-Hafiyy, 6/59.

17 Resâilü'l-Hikme, en-Nakzü'l-Hafiyy, 6/60-61.

18 Ahmet Yaşar Ocak, Osmanlı Toplumunda Zındıklar ve Mülhidler: 15-17. Yüzyıllar (İstanbul: Tarih Vakfi Yurt Yayınları, 1998), 94.

19 Osmanlı Arşivi, (BOA), Mühimme Defterleri [A. DVNS. MHM.d], No. 29, Gömlek No. 337. 
meyledip oğlunu oraya gönderdiği haber verilmiş, ancak bu habere itimad edilmemişti. Çünkü "Sünniyyü'l mezhep" olan bir kimsenin delâlete düşmeyeceği önemle vurgulanmış ve sadakatte "sâbit kadem" olacağ1 ifade edilmişti. ${ }^{20}$

Aynı tarihlerde Cebel-i Düruz'da başlamış olan bir isyanın aktörleri de aslında "Râfizi" olarak tanımlanabilecek olan Dürzîlerdi. Şam Kadısına gönderilen fermanda Curd, Metn, Garb ve Şuf İbn Ma'n'ın sakinleri olan Dürzîler, isyan ve itaatsizlik içinde bulunup, iltizamlarını ödemeyecek kadar ileri gitmişlerdi. Onların yüzünden bu kazaya bağlı olan nahiyelerde vergi toplanamaz olmuş, defter-i atik'i göstererek vergilerini ödediklerini söyleyerek yalan hükümde bulunmuşlardı. Üstelik vergilerini ödememekle kalmayıp, orada yaşayan diğer Müslüman ahaliyi de rahatsız etmeye başlamışlardı. Devlet gelirlerine ve köy halkına zarar vermeye başlayan bu isyancıların derhal şer' ile cezalandırılmaları gerekmekteydi. ${ }^{21}$

Vergi vermemek için ayaklanan Dürzîlerin isyanına son verilmesi için gönderilen hükümde ise ne Sünnîlik ne Şî̂lik ne de Râfızilikten bahsediliyordu. Dolayısıyla Dürzîlerin îtikadi özellikleri veya dini algıları da devletin üzerinde durduğu husus olarak görülmüyordu. Bu bağlamda vergi verdiği ve otoriteyi tanıdığı sürece kimliğin İslâmi veya heterodoks yüzünün anlam1nın yüzeysel kaldığı ortaya çıkmaktaydı. Devletin kendi kontrolü dışına çıkmaya çalışanlara karşı İslamlaştırma veya Sünnîleştirme politikası gütmesinin arkasında isyancıların başkaldırılarını dini sâikler üzerinden yapmalarının neden olduğu açıktı. Bir başka ifadeyle devletin bu hususta dini muhalefete müsamaha göstermediği ortaya çıkmakta, siyaseten nizâm-1 âlemin istikrarını bozmak isteyenleri ise kimlikleri üzerinden yorumlayıp dini araçsallaştırma gereği duymadığı gözlemlenmekteydi.

Meselenin Cebel-i Lübnan sakinleriyle ilgili olan bir diğer boyutu ise bölgenin önemli ticaret yollarına ev sahipliği yapmasıydı. Beyrut-Sayda çizgisinin sahip olduğu transit yol ticaretin aktif bir şekilde yürümesini sağliyor, köylü ve mukâtaacılar herhangi bir sorun çıkarmadıkları müddetçe bölgede görece zenginliğin getirdiği huzur hâkim oluyordu. Bu durumda da Cebel-i Lübnan Emirleri dağdaki otoritelerini güçlendirerek merkeze olan bağımlılıklarını en aza indirmeye hatta bağımsızlık yolunda ellerine geçecek olan her fırsatı değerlendirmeye çalışıyorlardı. İşte bu yüzden Osmanlı Devleti'nin Suriye bölgesinde en fazla uğraştı̆̆1 isyanlar bu sahada ve genelde Dürzîlerin liderliğinde ortaya çıkıyordu. 22 Üstelik Dürzîlerin otoriteye karşı yapacakları isyanlar, bölgenin ele geçirilmesinden iki yıl sonra gibi kısa bir zaman diliminde başlamıştı. Bu sebeple de devletin Dürzîlere yönelik yaklaşımında dini

20 Osmanlı Arşivi, (BOA), Mühimme Defterleri [A. DVNS. MHM d], No. 44, Gömlek No. 191.

21 Osmanlı Arşivi, (BOA), Mühimme Defterleri [MD], No. 29, Gömlek No. 70,25.

22 Abdurrahim Ebû Husayn, The View from İstanbul: Lebanon and the Druze Emirate in the Ottoman Chancery Documents (1546-1711) (New York: Centre for Lebanese Studies in Association with I.B. Tauris Publishers London, 2004), 12. 
parametreler yerine siyasi ve ekonomik dengeleri gözetmesini gerektirmiş, bu durum da merkez-taşra ilişkisinde hâkimiyet mücadelesinin izlerini ön plana çıkarmıştı.

\section{1848'deki Dava ve Dürzî Kimliği'nin Yeniden Okunması}

Cebel-i Lübnan'da siyasetin Dürzîlerin elinde olması hukuki sistemin de kendileri tarafından yürütülmesine yol açtı. Bölgedeki geleneksel hukuk sisteme göre de adalet düzeni Emir, Emir'in tayin ettiği kadı ve mukâtaacı konumunda olan şeyh veya mukaddamların yetkileri bağlamında hiyerarşik bir sistem doğrultusunda sağlanıyordu. Hırsızlık, kasten adam öldürme veya yaralama gibi ağır ceza davalarını ilgilendiren meseleler, doğrudan Emir'e veya onun tarafından göreve getirilen Dürzî kadının hükmüne bağlıyken, şahıslar arasında süregiden anlaşmazlıklar, borç, alacak meseleleri üzerinden hak arama gibi kabahatten ağır, cinayetten hafif olan cünha davalarına istinaf yolu açık olmak üzere bölgenin mukataacısı hüküm veriyordu. ${ }^{23}$

Dürzî ve Mârûniler arasında 1841 yılında çıkan ilk büyük çatışmadan sonra 1845 yılında Hariciye Nâzırı Şekip Efendi tarafından ilan edilen "Çift Kaymakamlık Nizamnamesi"ne göre ise, Emirliğin yetkisi dahilinde olan ve Emir tarafından hükme bağlanan hâd cezasını gerektiren cinayet davaları, kasten adam öldürme veya daha ağır suçlar içeren meseleler haricinde kaymakamların direk sorumluluğuna verilmeyerek kaymakamlık meclislerine de müzakere etme yetkisini vermişti. Kaymakamın yetkisini aşan suçlar için ise dava bütünüyle Sayda Müşîrine, oradan da Bâbrâli'ye havale edilecekti. ${ }^{24}$ Daha önce Emir tarafından atanan ve bölgenin adlî işlerini yürüten tek merci olan Dürzî kadı ise yalnızca kendi mezhebini ilgilendiren davalara bakacak, diğer mezheplerin her biri için ise birer kadı tayin edilecekti. ${ }^{25}$

Hâd cezalarını gerektiren davaların İstanbul'a gönderilmesi devletin doğrudan müdahale etmesine, böylelikle çatışmadan yeni çıkan ancak mezhepler arası kızışmaların ateşinin sönmediği Cebel-i Lübnan' da huzurun daha çabuk sağlanacağına dâir bir yaklaşımı ön görmekteydi. Ancak devletin yaklaşımı daha çok bölgedeki vâkıalar üzerinden belirlenen Nizamname harici düzenlemelerin pratik karşılıklarında kendisini buluyordu. Bu noktada Dürzîler ile Mârûniler arasındaki davalarda şahitlerin niteliğinden bahseden 1848 tarihli bir tezkire, Dürzîlerin "devlet nazarında İslam" görülmelerinin hukuki açıdan anlamını da yansıtmaktaydı. Islahat Fermanı öncesine kadar Zımmîlerin da-

23 Takiyüddin Süleyman, el-Kada fi Lübnan (Beyrut: Dârü'l-Cedid, 1996), 296.

24 Osmanlı Arşivi (BOA), Bâbıâli Evrak Odası Gelen Giden Defterleri, [BEO, GG], No. 1013, 23, 30.

25 Osmanlı Arşivi (BOA), Bâbıâli Evrak Odası Gelen Giden Defterleri, [BEO, GG], No. 1013, 17. 
valarda Müslümanlar üzerine şahitlik yapamayacağı net ve bunun İslam hukukuna aykırılığı keskin çizgilerle belirlenmişti ancak, ${ }^{26} 1856$ 'dan önce iki mezhep arasında meydana gelen bir olay üzerine hazırlanan tezkireye göre Zımmî şahitliği Cebel-i Lübnan'da daha erken dönemde varlığını göstermişti.

Dürzî Kaymakam Emin Arslan'ın Sayda valisi Vamık Paşa'ya gönderdiği mektupta kaymakamlığı dahilindeki Şemlan köyünde Mârûni Mihail Circis'in Dürzî şeyhlerinden Hüseyin'i öldürmesi ve davanın da Cebel meclisince görülmeyerek Beyrut mahkemesine havale edildiği yazıyordu. Mahkeme sürecini akamete uğratan mevzu ise Hüseyin'in yakınlarının olaya tanıklık eden Dürzîleri şahit olarak götürmeleriydi. Esasen Dürzîlerin Mârûnilere Mârûnilerin de Dürzîler üzerine şahitlik yapabileceğine dâir karar Şekip Efendi tarafından daha önce verilmişti ve Cebel meclislerinde uygulanıyordu. Ancak bu durum maslahat-1 âmmeden olan katl ve cinayet davasıydı ve Beyrut mahkemesi meselenin cinayet olması dolayısıyla şahitlerinden Müslüman olmaları şartını öne sürmüştü. Bu nedenle de Dürzî ahalinin şahitlikleri Ehl-i İslam'dan olmamalarından dolayı bu davada geçersiz olduğu için Beyrut mahkemesince kaymakamdan Müslüman şahit talep edilmişti.

Mesele Dürzîler açısından temelde kabul edilmekle birlikte, yaşadıkları köyde Müslüman olmaması ve katl olayını Dürzîlerden başkalarının görmemiş olması bir zarureti doğurmuştu. Bu sebeple Emin Arslan da Vamık Paşa'dan durumun halli için bir girişimde bulunmasını istedi. ${ }^{27}$ Paşa meseleyi aynen Hariciye Nezareti'ne ileterek Mihail'in Dürzî Hüseyin'i öldürmesi üzerine Dürzîlerin kendi taifelerinden birinin şahitlik yapıp yapmayacağını sordu. Yanına şahitlik meselesi uzadıkça katilin hapiste kalma süresinin de uzayacağı ve her iki tarafın mağduriyetinin artacağı detayını düştü. Çünkü Dürzîlerle Mârûniler arasında oluşacak her kriz çatışmaların soğumadan yeniden tekrarlanması demekti ve Paşa olabildiğince bunun önüne geçmeye çalışıyordu. Bu sebeple de bu hususun bir daha tekrarlanmaması için bu gibi zorluklara dâir bir düzenlemenin gerekliliğini belirterek çözüm talep etti. ${ }^{28}$

Şekip Efendi'nin tarafların birbirleri üzerine şehadetlerini kabul etmesine rağmen, cinayet davalarının dışarıda tutulmasının İslam hukuku çerçevesinde alınmış bir karar olmadığı açıktı. Dürzîler ve Mârûniler arasındaki düşmanlığın ciddi çatışmalarla sonuçlanması ve her iki tarafın da kayıplarının fazlalığı, cinayet davalarında birbirleri üzerine yapılacak şahitliğin mümkün

26 Islahat fermanı öncesi Osmanlı topraklarında şahitlik meselesinde İslam hukuk normlarının uygulanmış olduğu açık olmakla birlikte, birtakım istisnalar da mevcuttu. Öldürülen şahsın bulunduğu yerde hiç Müslüman yaşamaması gibi nedenlerle gayrimüslim şahitliğine de başvurulabiliyordu. Detaylı bilgi için bk. Sedat Bingöl, Tanzimat Devrinde Osmanlıda Yargı Reformu: Nizamiye Mahkemelerinin Kuruluşu ve İşleyişi 1840-1876 (Eskişehir: Anadolu Üniversitesi Edebiyat Fakültesi Yayınları, 2004), 33-34.

27 Osmanlı Arşivi, (BOA), Hariciye Mektûbi Kalemi [HR. MKT.], No. 22 Gömlek No. 50,2.

28 Osmanlı Arşivi, (BOA), Hariciye Mektûbi Kalemi [HR. MKT.], No. 22 Gömlek No. 50, 1. 
olamayacağ1 neticesini doğurmuştu. Dolayısıyla mevcut "husîmet-i kadîm" nedeniyle bu gibi istisnaların dahi daha büyük zararlara yol açmaması açısından görmezden gelinmesi gerekiyordu. ${ }^{29}$ Diğer taraftan meselenin şer'î boyutu da ortaya çıkıyor ve cinayet davalarında Ehl-i Zımmî̀'den herhangi birinin Dürzîler üzerine şahitlik yapması problemine yer veriliyordu. Yani Dürzîler cinayet davasında şahit olacak kadar Müslüman değildi ancak bir gayrimüslimin de kendileri üzerine şahitlik yapabilmeleri fazladan bir izaha ihtiyaç duymaktaydı. Bu nedenle de kalıcı hukuki bir çözümün sağlanması şarttı.

\section{Osmanlı Mezhep Politikasının Dava Sonucuna Yansıması}

Osmanlı devletinin modern anlamda kurumsallaşmasıyla idari, askeri olduğu kadar hukuki alanda da reformist bir düzene geçildiğinin en önemli göstergesi olan Tanzimat Fermanı, merkezde olduğu gibi taşrada da etkilerini göstermeye başlamıştı. Bununla birlikte mezhep siyasetinin ve hukukunun baskın olduğu Cebel-i Lübnan'a yeni reformist devlet anlayışını empoze etmek beklendiği kadar kolay olmamıştı. Ancak ne olursa olsun sıcak çatışmadan sonra kurulan Çift Kaymakamlık Sistemi her ne kadar ikili yönetimi temsil etse de Tanzimat merkeziyetçiliğinin bölgede işlenmesi üzerine inşa edilmişti. Bu aşamada devletin toplumla olan ilişkisinde takip etmek istediği merkezi anlayış, o zamana kadar dini çatı altına girmeyen Dürzîler üzerindeki farklı yansımalarını da gün yüzüne çıkarmaya başlamıştı. Dolayısıyla Sadaret'e Dürzîlerin İslami kimlikleri bağlamında giden bu davanın sonucu, Osmanlı Dürzîlerinin de hangi çatı altında tanımlanacakları sorusunun da cevabı olacaktı.

Sadaret'e bildirilmesiyle birlikte mahallinde yapılan yorumlar ve yazışmalar neticesinde önce Meclis-i Vâlâ'ya giden dava, Meşîhat'e ulaşarak hangi usulün takip edileceği soruldu. Meşîhat'ten gelen fetva ise meselenin pragmatizme dayanan şeklini gösterir şekildeydi. Fetvâhane'den alınan fetva mûcebince Şeyhülislam Arif Hikmet Efendi önce Dürzîlerin îtikâdi durumlarını ön planı çıkardı, sonra da iki mezhep arasındaki düşmanlığa yer verdi. Şeyhülislam’a göre Dürzîler ile Mârûniler arasındaki düşmanlık davaların şer'an çözülmesini mümkün kılmıyordu. O yüzden de bu gibi istisnaların uygulanması meclislerin sorumluluğuna bırakılmıştı:

“Ma'ruz-u çâkerikemîneleridir ki,

Enmele zîb-i tevkîr olan işbu tezkire-i sâmiye-i âsâfâneleri müfâd-1 âlisi ve Sayda Valisi atûfetlu Paşa hazretlerinin tahrirât-1 melfufeleri meali-i rehin ittıla-1 senâverânem olarak husûs-u mezkûr fetvâhâne'ye arz olundukda cânib-i fetvâhâne'den verilen pusula leffen vusûl-u savb-1 vâlây-1 âsâfâneleri kılınmış ise de bu kavmin iddiaları başka ve zahir halleri başka olup mâ'lum-u âli

29 Osmanlı Arşivi, (BOA), Meclis-i Vükelâ Evrakı, [MVL], No. 31, Gömlek No.34. 
vekâletpenâhilere buyurulduğu üzere tarafeyn'in beynlerinde husûmet-i kadîm muâdât-1 külliye olduğuna mebni bunların münâzaa ve iddiaları şer'an fasl olunması mümkün olamayacağından husûs-u mezkûr mecâlis marifetiyle fasl olunması enseb mülâhaza olunmuş ise de yine ol bâbda emr-ü irâde hazreti men lehu'l emrindir." 30

Burada dikkate şayan olan durum ise Meşîhat'ten gelen görüş karşısında devletin gösterdiği reaksiyon olmuştu. Çünkü Meşîhat'in fetvası bir fikir beyanı olmakla birlikte ifadelerin muğlaklığı netlik vermemekteydi. Nitekim Dürzîler Ehl-i İslam'dan sayılmamışlardı belki ama bunun dışında da tutulmamıştı. Sadaret Ârif Hikmet'ten gelen görüşün temel aldı ancak kapalı kalan kısımları tavzih ederek yaklaşımını ortaya koydu. Daha açıkçası Meşîhat “içidışı bir değil" diyerek îtikaden meseleye yaklaşırken Sadaret meseleye hukuk yönünden yaklaşarak politik tavrını sergiledi:

“Cebel-i Lübnan'da mutavattın Düruz ve Nasâra taifesinden birbirleri beyninde vuku bulan deâvide Düruzun Nasâra ve Nasâra'nın Düruz üzerine makbûliyeti şehadetleri icra olunmakda ise de beynlerinde husûmet-i kadîm bulunması cihetiyle Nasâra'dan Mihail nam şahıs Düruz'dan Hüseyin mukaddem'i katl ve idam ederek verese-i Düruzun şühud ikame edip Nasâra'dan şahid götürülmek üzere cevab verildiği ve katil-i merkum ilel ân mahbusda bulunduğu beyanıla icrây-1 îcab istizan-1 şâmil Sayda Valisi atûfetlü paşa hazretlerinin şukkay-1 mevrûdesi Meclis-i Vâlâ'ya verilip onun üzerine kaleme alınan mazbatada beyan olunduğu vecihle cenâb-ı fetvâhâne'den alınan ifadeye nazaran verese-i Ehl-i İslam veyahut ehl-i zimmetten ikâme-i beyyine ile isbât-1 müddea edebilecekleri halde iktizây-ı şer'iyye-'nin icrâsı, şahid bulamadıkları taktirde katil-i mesfur hakkında bilâ sübut şer'an nesine lazım geleceğinden tahliyesi ve bundan böyle tâifeteyni mezbûreteyn beyninde zuhûr eden katil maddelerinde ikâme olunacak şâhidlerin vech-i meşru' üzere ikâme ettirilmesi zımnında sûret-i mahremiyetde olarak vâliy-i müşârun ileyh hazretlerine tahrirât-1 senâveri tasdîrine ne vecihle irâde-i seniyye hazret-i şâhâneye müteallık ve şerefsüdûr buyrulur ise ona göre iktizası icra olunacağı ve mezkur mazbata tahrîrât-ı manzûr-u âli buyrulan encemine takdim kılındığı beyanılla tezkire" ${ }_{31}$

Sadaret'ten gelen hükme göre bundan böyle her iki mezhep grubunun katl davalarında da birbirleri üzerine şahitliklerine başvurulabileceğinin ruhsatı verilmişti. Bu durum aynı zamanda Dürzilerin Osmanlı hukukuna yaklaşıp siyasi kimliklerinin yanı sıra hukuki olarak da Osmanlılık temayüllerini sergilemelerinin yanında, Dürzîlerin merkeze İslam kimliği üzerinden yaklaşma eğiliminin devletçe karşılı̆̆ını ne ölçüde bulduğuna da işaret ediyordu.

30 Osmanlı Arşivi, (BOA), Meclis-i Vükelâ Evrakı, [MVL], No. 31, Gömlek No. 34.

31 Osmanlı Arşivi, (BOA), Amedî Kalemi, [A.AMD], No.8, Gömlek No.1. 
Bâbıâli cemaatlerin aralarındaki kendi hukuklarına müdahale etmeyerek bir anlamda mezhepsel ilişkilerin hukukla örtüşmesini sağlamayı planlıyordu. Bu sebeple de önce Fetvâhaneden aldığ1 görüşü değerlendirip oradan hangi mananın çıktığını açıklayarak muğlaklığı ortadan kaldırmıştı. Mesele esasen bölgesel bir hassasiyete sahip olduğu için Fetvâhane îtikadi çekincesini belirtmişti. Bu yüzden de Beyrut meclisinin davayı kendince çözmesi Meşîhat'in de işine gelen bir durumdu. Devlet ise fetvaya istinaden soruna köklü bir çözümle yaklaşmış ve yalnızca bu davada değil bundan sonra ortaya çıkacak davalarda da iki cemaatin birbirleri üzerine şahitliklerini geçerli kılmıştı. İstanbul'un aldığı kararlar Fetvâhaneden karşılığı olan kararlardı ancak bunu hukuki bir zemine oturtarak Meşîhat'in çekinceleri nedeniyle üzerini örttüğü meselelere açıklık getirmek de bölge politikası açısından önemli olan çabalardi.

Fetvâhane'nin bir diğer muallakta bıraktığı mesele ise kararın Beyrut meclisince verilmesinin istenmesiydi. Sadaret bu görüşe de müdahale ederek hükmü Beyrut kadısına bırakmamayı tercih etmişti. Çünkü Beyrut'a kalsa Dürzîler zaten Ehl-i İslam'dan sayılmıyordu ve şahitlikleri geçerli değildi. Sadaret ise bu yükü kaldırmak istemediği için Beyrut'a kararı bırakmayarak kendi hükmünün uygulanmasını emretmişti.

\section{4. İngiltere'nin Davaya Müdahalesi Karşısında Dürzî Kimliğinin Yeniden Tanımlanması}

19. yüzyılla birlikte Mârûnilerin Fransa'ya, Dürzîlerin İngiltere'ye, Ortodoksların Rusya'ya, Rum Katoliklerin ise Avusturya'ya yaslanmasıyla Cebel-i Lübnan, dini ve siyasi parçalanmışlığın uluslararası arenadaki karşılığı olmuştu. ${ }^{32}$ Dolayısıyla da bu durum, Tanzimat'ın öngördüğü merkeziyetçiliğin bölgede uygulanması noktasında karşılaşılan en büyük problem olarak Osmanlı Devleti'nin karşısında duracaktı. Devlet Cebel-i Lübnan'a ne kadar bütüncül bakarsa, Avrupa o kadar mezhepçi ve ayrık görüyordu. Osmanlı Devleti iç politikada ne kadar tekil davranırsa Avrupa o kadar müdahil oluyordu. Devletin İngiltere olmadan halkı idare edemeyeceği düşüncesinin elçiler tarafından tahrik amacıyla yayılmaya başlaması ise olası baskılara zemin hazırlamanın işaretleriydi. ${ }^{33}$

Mârûni cemaati için Fransa'nın Cebel-i Lübnan'daki varlığ lerini kurmaları açısından ve Osmanlı Devleti'ni bütünüyle bölgeden çıkarmak için arzu edilen bir durumdu. Ancak Avrupa etkisi Dürzîler açısından daha farklı algılanıyordu. Dürzî cemaatinin kilise gibi dini bir otoriteye sahip olmaması, ayrıca destek aldıkları İngilizlerle aynı dinin mensubu olmamaları,

32 Adil İsmail, “Ahdü'l-favda ve'l-idḍirabat 1840-1860: Taḳsim ve'l-fitenü't-țaifiyye”, Lübnan fì tarîhihi ve turâ sihi (Beyrut: Merkezü'l-Hariri's-Sekâfe, 1993,) 1/347.

33 Osmanlı Arşivi, (BOA), İrade Dahiliye, [İ.DH.], No. 52, Gömlek No.2580. 
aralarındaki ilişkinin daha zayıf olmasına ve Dürzîlerin Osmanlıyla olan bağının çok fazla etkilenmemesine yol açtı. 1841'de Colonial Rose ile yaptıkları görüşmelerde topraklarını geri alacakları taahhüdü ve Dürzî lider Numan Canbolat'ın İngiliz kraliçesinden istediği resmî koruma talebinin olumlu karŞılanmasına rağmen, ${ }^{34}$ çatışma sonrasında Benî Neked ve Canbolatların Osmanlı yetkililerine İngiliz korumasını artık istemediklerini, devletin halkına karşı olan desteğini takdir ettiklerini bildirmeleri bunun bir ispatı gibiydi. ${ }^{35}$

Bu durum biraz da hem Dürzîlerin hem de Mârûnilerin Tanzimat'1 anlama ve yorumlama biçimiyle alakalıydı. Osmanlı Devleti'nin uygulamaya çalıştığı merkeziyetçi anlayış, bölgedeki cemaatler açısından alışılagelen bir durum değildi. Ancak bölgede 1830'larla birlikte gelişim gösteren mezhepçi anlayış da bölge halkı açısından sevinçle karşılanmıyordu. Dolayısıyla sonucu ne olursa olsun merkezden atanan yetkili, iki cemaat arasındaki problemlerin çözümü için gereken huzuru sağlayabilirdi. Yine de İngiltere'nin otoriteye karşı gelen Dürzî ileri gelenlerinin Bâbıâli tarafından cezalanmasının önüne geçmesi, Dürzîler arasında İngiliz sempatisinin oluşmasını sağlamıştı. Bu aracılık aynı zamanda devletle aralarında oluşabilecek tehlikelerin bertaraf edilebileceği hususunda, Dürzî toplumu için Osmanlı korkusunun da giderildiği anlamını taşıd1. ${ }^{36}$

İngiltere ise Dürzîler üzerinden yürüttüğü politikanın hukuki dayanaklarını idari ve mali olduğu kadar ideolojik ve dini meseleler üzerinden de ele almaya çalışıyordu. Bölgedeki Katolik misyonerlerin faaliyetleri üzerine Dürzîlerin yoğun olduğu yerlerde mezhebi faaliyetlerde bulunmaya başlayan İngiliz misyonerler, Havran, Şuf, Hasbeya ve Raşeya' da Dürzîlerle kurdukları yakın ilişkiler sayesinde Protestanlığın beklenen düzeyde yayılmasını sağlayamasalar da himaye hedefini tutturmayı başarmışlardı. ${ }^{37}$

Protestanlığın Dürzîler arasında ciddi anlamda taraf bulmaması İngiltere'nin Dürzîlerin Osmanlı Devleti nazarındaki dini statülerine dâir fikir ve yorumlarını hukuki meselelerin konusu haline getirmesini sağlamıştı. Bu bağlamda Dürzîlerin ve Mârûnilerin aralarında vuku bulan davalarda birbirleri üzerine şahitlik etmeleri hususu, İngiltere'nin ilginç bir pazarlığa girmesine yol açtı. Konsolosluk, mahkemelerdeki bu uygulamanın peşine düşmüş, İngiliz konsolos Moore, Hariciye Nezâreti'ne yazdığı mektupta Ehl-i Nasâra'dan olanların nasıl olur da Ehl-i İslam üzerine şahitlik yapabildiklerini sormuştu. Avrupa'nın, tek bir siyasi çatı altında uzun zaman yaşamış ve

34 Ḥassan al-Haysami, el Murâsalatü'l-ictimâ'iyye ve'l-iḳtisâdiyye li zu'amai Cebel-i Lübnan hilali selâseti'l-kurun (Beyrut: y.y. 1979 - 1980), 50.

35 Osmanlı Arşivi, (BOA), Irade Dahiliye [i். DH], No. 249, Gömlek No. 15283.

36 Haluk Ülman, “1840-1845 Arasında Suriye ve Lübnan'ın Durumu ve Milletlerarası Politika”, Ankara Üniversitesi, SBFDERGISI 18/3 (Mart 1963), 254.

37 Emel Mihail, Beşşur, Suriye ve Lübnan fi așri'l-ıșlahi'l-Osmani: Hakâbetü't-Tanzimat min seneti 1840 ilâ 1880 (Trablus: El-Müessesetü'1-Hadise li'1-Kitâb, 2006), 63. 
bu çerçevede zaman zaman ortak hukuki ilkelere ve hatta kültüre sahip olmalarına rağmen Cebel-i Lübnan'daki cemaatleri birbirinden kolayca ayırarak mezheplere göre politik söylemlerini oluşturduğu vakiyd. ${ }^{38}$ Şimdi ise İngiltere bölgede Dürzîler üzerinden başka bir ayrıma giderek İslam çatısı altında yaşayanların hukuki statülerini sorguluyordu.

Hariciye Nâzırlığının Vamık Paşa'dan mahkemelerde nasıl bir uygulama yapıldığının detaylarını istemesi üzerine Paşa'nın yazdığg cevap net ve izaha muhtaç olmamakla birlikte, Dürzîlerin dini kimliklerinin mahkemelerdeki karşılığının yorumlanması meselesini yeniden gündeme getirdi. Vamık Paşa'ya göre, Dürzîler ile Mârûnilerin mahkemelerde birbirleri üzerindeki şahitlikleri meselesi Şekip Efendi zamanında kabul edilmiş ve süreç de bu düzenleme doğrultusunda ilerlemekteydi. Devlet'ten gelen hükme göre de Dürzîlerin İslâmi kimlikleri ve hukuki statüleri açıklığa kavuşmuştu. Bununla birlikte konsolosun iddiası Hristiyan cemaatlerin Dürzî üzerine değil de Ehli İslamdan olan diğer mezhepler üzerine şahitliğini kapsamaktaydı ki bu durum zaten Şekip Efendi tarafından dahi kabul edilmemişti. Yani Mârûnilerin yalnızca Dürzîler için şahitlik yapabildikleri belirtiliyor, üstelik bu durum bir istisna olarak dahi kabul edilmiyordu. Ancak şahitlik meselesi Nizamnamenin 11. Maddesinde yer alan "mecmu' davalar âdat-ı kadîme üzere hakkaniyetle çözülecektir" ifadesi üzerine oturmaktaydı. Bu noktada Cebel-i Lübnanlı Dürzî ve Mârûniler arasındaki ilişkinin hukuka adapte edilmesi uygulamanın istisnailiğini bozmuyordu. Dolayısıyla da gayrimüslim'in Müslüman lehine veya aleyhine şahitlik yapabilmesi bölge dışında uygulama alanına sahip değildi. Paşa da konsolosun Dürzî Kaymakam Mir Emin'in kafasını bulandırmaktan başka bir şey yapmadığını, Nizamnamede yer alan düzeni değiştirme tasavvurunda olduğunu iddia etmekteydi. ${ }^{39}$

İngiltere'nin Dürzîler üzerindeki himaye politikası, Fransa'nın takip ettiği yoldan farklı olarak önce 1820'lerle birlikte bölgede kurdukları eğitim yoluyla başlamış, Dürzîlerin eğitim ihtiyaçlarının giderilmesi ve İngiliz misyonunun kazandırılması hedeflenmişti. Yanı sıra misyoner faaliyetleri için de çaba gösterilmiş olsa da İngiltere her iki alanda da Dürzîlere karşı tam bir başarı elde edemedi. Ancak Dürzî ileri gelenleriyle kurulan siyasi ilişkiler Osmanlı Devleti'nin merkezden uygulamak istediği hukuk merkezli politikalara karşı İngiltere'den gelebilecek müdahalelerin önünü açtı. Bu davada olduğu gibi İngiltere'nin Dürzî davalarında cemaatle devlet arasına girmesi bir anlamda bölgedeki hegemonyasının da izlerini taşımaktaydı. İngiliz konsolosların karma nitelikli dahi sayılmayacak olan davalarda, yani esasen devletin kendi

Ussama Makdisi, The Culture of Sectarianism: Community History And Violence in NinetenthCentury Ottoman Lebanon (Berkeley: University of California, 2000), 24.

39 Osmanlı Arşivi, (BOA), Hariciye Mektubi Kalemi, [HR. MKT.], No. 36, Gömlek No. 42,2. 
tebaası arasında çıkan anlaşmazlıklarda kendi muhakeme usullerini takip etmeye çalışmaları, Fransız meslektaşlarıyla girdikleri siyasi rekabette hukuk nosyonunu da özenle kullandıklarını göstermekteydi. Bu noktada İngiltere'nin de Fransa gibi yargı alanındaki işlevini Tanzimat sürecinde de korumaya özen gösterdiği dikkati çekmekteydi.

\section{Sonuç}

Şî̂liğin İsmâililik kolunun bir uzantısı olan Dürzîler Sünnî ideolojinin dışında kalan bir topluluk olup, Tanrının birliği, îtikâdi farklılıkları ve felsefeleri bağlamında Osmanlı Devleti'nde Ehl-i Sünnet dışında yer alan mezheplerden biriydi. Bu nedenle de devletin yönetim biçimi açısından Dürzîlerin Osmanlı "Millet Sistemi"ndeki yerleri ve siyasi pozisyonlarının yanı sıra hukuki statülerinin anlamı da önem arz ediyordu. Çünkü devlet Dürzîleri Ehl-i İslam'dan sayıp cizye almamaya karar vermişti öyleyse Ehl-i İslam'dan olan birinin adli meseleleri de İslam hukukuna göre çözülmeliydi. Ancak Dürzîlerin evlenme, boşanma, miras ve vakıf gibi farklı İslam hukukuna aykırı olan ilkeleri vardı ve devletin mezhep siyasetini buna göre belirlemesi gerekiyordu. Dürzîlerin bölgede kurdukları iktidar ve bu iktidar bağlamında sağladıkları istikrar ise devletin o dönem daha önem verdiği meselelerin başında geliyordu. Bu nedenle siyaseten Osmanlı Devleti Lübnan bölgesini fethettiğinde otoritenin sahipleri olan Dürzîlerin hâkimiyetlerini tanımış, mezhep çeşitliliğine rağmen Cebel-i Lübnan'da siyaset Dürzî Emirler eliyle yürütülmeye devam etmişti.

Cebel-i Lübnan'da siyasi ve hukuki sistemin tökezlemesi ise 19. Yüzyıla denk gelmekteydi. Dürzîlerin Mârûnilerle yaptıkları çatışma siyasi güçlerini kaybetmelerine neden olmuş, Tanzimat modernleşmesi ise Dürzîlerin hem siyasi hem de hukuki kimliklerini tanımlamada devlet merkezli bir kapı açmıştı. Bu anlamda 1845'de kurulan Çift Kaymakamlık Sistemi, yalnızca mezhepleri birbirinden ayrıştırmakla kalmamış, Tanzimat hukukunun gerektirdiği çerçevede mahkemelerin ve kadıların yetkilerinin de yeniden belirlenmesini gerektirmişti. Bu süreçte Cebel'de Dürzîler ve Mârûniler açısından adalet mekanizmasının işlemesi de mezhep kimliğinin Osmanlı Devleti nazarındaki karşılığına bağlanmıştı. Dürzî cemaati için Müslüman Osmanlı, her ne kadar Gülhane Hattı Hümayunu'yla tebaanın eşitliğini ilan etmiş olsa da Ehl-i İslamdan olan Dürzîleri himaye etmeliydi.

Osmanlı yönetimi ise Dürzîler açısından çerçevesi belirli bir hukuki statü belirlememişti. Bu nedenle de Meşîhat'in Dürzîllerin o zamana kadar sorgulanmamış olan kimliklerine isim koyması kolay olmamış ve kendisine gelen soruyu cevapsız bırakmak durumunda kalmıştı. Ancak Devlet tarafında hukuk-kimlik ilişkisi üzerinde çok fazla hassasiyete sahip olan bir noktaydı. Dolayısıyla Sadaret, Cebel-i Lübnan'da Dürzî ayanın siyasi otoritesini tamamen yitirmesiyle gün yüzüne çıkan boşluğu, Dürzîleri ecẑ̂a-i Íslam'dan addederek 
olabildiğince kendi hukuku içerisine alması şeklinde doldurmak istemiş, Dürzî davalarının çözümü adalet sisteminde devletin istikrar politikası çerçevesinde çözülmeye çalışılmıştı. Sonucunda da Dürzî kimliği yeni hukuki sistemde yerini almış, Osmanlı Devleti yıkılıncaya kadar da Ehl-i İslam çatısı altında korunmaya devam etmişti.

\section{Kaynakça}

Abu-Husayn, Abdurrahim. The View from İstanbul: Lebanon and the Druze Emirate in the Ottoman Chancery Documents, (1546-1711). Centre for Lebanese Studies in association with I.B. Tauris Publishers London, New York, 2004.

Abu-Izzeddin, Nejla M. The Druzes: A New Study Of Their History and Faith. Leiden: E.J. Brill, 1984.

Haysami, Hasan. el-Murâsalatü'l-ictimâ'iyye ve'l-iḳtiṣâdiyye li zu'amai Cebel-i Lübnan hilali selâseti'l-kurun. Beyrut: y.y. 1979 - 1980.

Bağlıoğlu, Ahmet. İnanç Esasları Açısından Dürzîlik. Ankara Okulu Yayınları, Ankara, 2004.

Bağlıoğlu, Ahmet - Ünalan, Sıddık. Ortadoğu'da Marjinal Bir Topluluk Dürzîler: Son Rapor. Elazığ: Fırat Üniversitesi İlahiyat Fakültesi, 2005.

Beşşur, Emel Mihail. Suriye ve Lübnan fi așri'l-ișlahi'l-Osmani: Hakâabetü't-Tanzimat min seneti 1840 ilâ 1880. Trablus: el-Müessesetü'l-Hadise li'l-Kitâb, 2006.

Bingöl, Sedat. Tanzimat Devrinde Osmanlıda Yargı Reformu: Nizamiye Mahkemelerinin Kuruluşu ve İşleyişi 1840-1876. Eskişehir, Anadolu Üniversitesi Edebiyat Fakültesi, 2004.

BOA, Osmanlı Arşivi, Bâbıâli Evrak Odası Gelen Giden Defterleri [BEO, GG] 1013.

BOA, Osmanlı Arşivi, Mühimme Defterleri [A. DVNS. MHM.d], No. 44, Gömlek No. 191.

BOA, Osmanlı Arşivi, Mühimme Defterleri [MD], No. 29, Gömlek No. 70,25.

BOA, Osmanlı Arşivi, Hariciye Mektûbi Kalemi, [HR. MKT.], No. 22 Gömlek No. 50,2.

BOA, Osmanlı Arşivi, Hariciye Mektûbi Kalemi, [HR. MKT.], No. 22 Gömlek No. 50,1.

BOA, Osmanlı Arşivi, Meclis-i Vükelâ Evrakı, [MVL], No. 31, Gömlek No.34.

BOA, Osmanlı Arşivi, Amedi Kalemi, [A.AMD], No.8, Gömlek No.1.

BOA, Osmanlı Arşivi, Irrâde Dahiliye [İ. DH], No. 249, Gömlek No. 15283.

BOA, Osmanlı Arşivi, Hariciye Mektûbi Kalemi, [HR. MKT.], No.36, Gömlek No. 42-2.

BOA, Osmanlı Arşivi, İrade Dahiliye, [I.DH.], No. 52, Gömlek No.2580.

Churchill, Charles Henry. The Druzes And The Maronites: Under The Turkish Rule From 1840- 1860. Reading: Garnet Publishing, 1994.

Do Sasi, Silvester. Medhal ilâ Diyâneti Düruz. çev. İsa Tannus, Şam: Dârü'l-Vataniyyetü'l-Cedîde, 2011.

Firro, Kais. A History of The Druzes. Leiden: E.J. Brill, 1992.

Hüseyin, Muhammed Kâmil. Tâifetü'd-Düruz: Tarihuha ve akaiduha. Mektebetü'l-Diraseti't-Tarihiyye. Kahire, 1962.

İsmail, Adil. "Ahdü'l-favda ve'l iddirabat 1840-1860: Taḳsim ve'l fitenü't-țaifiyye", Lübnan fî tarîhihi ve turâ sihi. 1/321-357. Beyrut: Merkezü'l-Hariri's-Ṡekâfe, 1993.

Makdisi, Ussama. The Culture of Sectarianism: Community History And Violence in Ninetenth-Century Ottoman Lebanon. Berkeley: University of California, 2000. 
Ocak, Ahmet Yaşar, Osmanlı Toplumunda Zındıklar ve Mülhidler: 15-17. Yüzyıllar,. İstanbul: Tarih Vakfı Yurt Yayınları, 1998.

Resâilü'l-Hikme. Beyrut: Dâru Liecli'l-Meârife, 1986.

Şenzeybek, Aytekin. Ana Kaynaklarına Göre Dürzîlik. Emin Yayınları, Bursa, 2012.

Takiyüddin, Süleyman. el-Kada fi Lübnan. Beyrut: Dârü'l-Cedid, 1996.

Ülman, Haluk. “1840-1845 Arasında Suriye ve Lübnan'ın Durumu ve Milletlerarası Politika". Ankara Üniversitesi, SBF Dergisi 18/3 (Mart 1963), 254. 


\section{The Reflection of the Tanzimat Law on Druze Identity in Mount Lebanon in the Light of a Murder Case}

\section{(Extended Abstract)}

By the expansion of its territories short after the establishment, the Ottoman Empire shaped its political, military, economic and cultural building blocks while seeking to determine the legal system within a framework of a certain discipline. As a basic discipline in the systematization of law, the principles of Islamic Law and Hanafi sect have been adopted as general and particular references respectively. However, some religious groups in the Arab provinces, which were added to the State system with the conquest of Yavuz Sultan Selim at the beginning of the 16th century, had to be redefined within the framework of Islamic legal principles. From this point of view, this study examines the status of the Druze identity in the sectarian policy of the Ottoman State through a murder case in Mount Lebanon.

Although small in number, the Druzes, were a community that used their military abilities well, had sectarian unity and social solidarity, so they could hold political power and organize a potential uprising in a short time. For this reason, when the Ottoman Empire conquered Mount Lebanon, it recognized the political authorities of the Druze who ruled the region and did not question whether they were out of ahl al-Sunnah. Therefore, the reaction of the State against the occasional tax rebellions of the Druze leaders did not have religious basis. However, the Druze sect which is the extension of the Ismaili branch of Shi'ism had a different system of faith such as the unity of God, the form of life after death, and the uniqueness of Hâkim. For this reason, the meaning of the legal status of the Druzes was important for the form of government of the State as well as the political positions of them in the Ottoman "nation system".

Until 19th century, there was no political mean for being under the roof of ahl al-İslam in the nation system for the Druzes. But the war that erupted at the beginning of the century indicated that the system should change in Mount Lebanon. The conflict between the Druze and the Maronites caused them to lose their political power, while the modernization of Tanzimat opened a State-centered door in defining the Druzes' political and legal identities. In this process, the functioning of the justice mechanism was linked to the equality of the sectarian identity in Mount Lebanon in the eyes of the Ottoman State. For the Druze community, although the Muslim Ottoman had declared the equality of the subjects with the Gulhane Hattı Humayun, it should have protected the Druze from the people of ahl al-İslam.

In this sense a murder case that happened in 1848 between Druzes and Maronites was a significant example of determining the status of the Druzes in the nation system. Although the Islamic identity of the Druze was brought 
out by the ulama of the region from time to time, the Ottoman state did not pursue an exact policy about it. Nevertheless, the region beginning to gain international importance and the inter-communal system beginning to collapse at the same time needed the State to intervene directly from time to time. On the other hand the nation system was placed in a different frame after the Tanzimat edict issued in 1839. For this reason, the Ottoman State needed to redefine the religious identity of the communities outside the ahl al-Islam. The Druzes of Mount Lebanon had an important position both in terms of their activities in the region and their relations with the State. Therefore the decision to be made about the Druzes could affect not only Druzes but also the whole region.

The murder case in 1848 was the focus of the negotiation between the State and Mashikhat. The Ottoman State wanted to pursue a policy that would not keep the Druzes out from its Islamic border. Thus, the State had pragmatic intentions for the results of the case. Because every step to be taken in Mount Lebanon, a region that was just saved from recent conflicts, had to be in accordance with its own charge. So much so that the issue extended to an international intervention, and the outcome of the case was even questioned by Britain who carried out patronage policy in the region. In other words, there was a criticism against the system that the Ottoman state determined according to the Islamic law over the Islamic identity of the Druzes. The State could not accept such objection. As a result despite the British efforts the Druze identity has been placed in a political framework and the state has managed to take this non-Sunni subject under its roof.

Nevertheless, this decision was not made easy for the State. The Ottoman administration did not set a certain legal status for the Druze. Therefore, it was not easy for the Mashikhat to name the Druzes' identity, which had not been questioned until then, and he had to leave the question unanswered. However, it was a point on the State side that had a lot of sensitivity to the relationship between law and identity. Therefore, the State wanted to fill the gap that emerged in the Mount Lebanon with the Druze candidate's political authority by including the Druze from part of İslam as much as possible, and the Druze cases was tried to be solved within the justice system within the framework of the stability policy of the State. As a result, the Druze identity took its place in the new legal system and continued to be protected under the roof of the Islamic nation until the Ottoman Empire collapsed. 